\title{
A Rare Cause of Small Bowel Obstruction: Incarcerated Obturator Hernia
} ince Barsak Obstrüksiyonunun Nadir Bir Nedeni: Inkarsere Obturator Herni

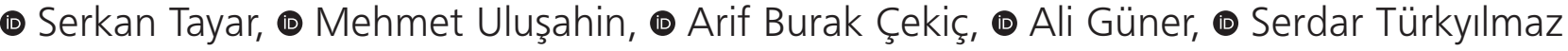 \\ Karadeniz Technical University, Farabi Hospital, Clinic of General Surgery, Trabzon, Turkey
}

\section{Abstract}

Obturator hernia $(\mathrm{OH})$ is a rare type of hernia caused by protrusion of the pelvic contents through the obturator foramen. It usually affects elderly, debilitated women. Patients may present with the symptoms of mechanical intestinal obstruction. Delayed diagnosis or misdiagnosis is frequent due to non-specific signs and symptoms. In this paper, we present the case of $\mathrm{OH}$ in two patients. Both patients were admitted to the emergency department with the symptoms of ileus. Incarcerated $\mathrm{OH}$ diagnosis was made after evaluations. One of the patients, who underwent emergency surgery, had necrosis and small intestine resection was performed. $\mathrm{OH}$, defect was repaired in both patients and serious postoperative complications developed. $\mathrm{OH}$, is a clinical condition associated with high morbidity and mortality in incarcerated cases. There are many open and laparoscopic methods in treatment. Early diagnosing may be life-saving.

Keywords: Obturator, herni, mechanic intestinal obstruction, ischemia, Howship-Romberg sign
Obturator herni $(\mathrm{OH})$ intraabdominal organların obturator foramenden pelvis içine girmesi sonucu oluşan bir herni çeşididir. Genellikle kadınlarda görülür. Hastalar ileus semptomları ile gelebilir. Ayırıcı tanıda bir çok farklı klinik durum mevcuttur; bu nedenle tanıda gecikme veya yanlış tanı karşılaşılabilen durumlardır. Bu yazıda $\mathrm{OH}$ nedeni ile opere edilen iki hastaya ait bilgiler sunulmuştur. Her iki hasta da acil servise ileus semptomları ile başvurdu. Yapılan tetkiklerde inkarsere $\mathrm{OH}$ tanısı konuldu. Acil olarak opere edilen hastaların birinde nekroz mevcuttu ve ince barsak rezeksiyonu uyguland. Her iki hastada da $\mathrm{OH}$ defekti primer olarak tamir edildi. Postoperatif süreçte ciddi komplikasyon ya da mortalite gelişmeyen hastalar taburcu edildi. OH, özellikle inkarserasyon durumlarında morbidite ve mortalitesi yüksek seyredebilen bir klinik durumdur. Tedavisinde açık ve laparoskopik bir çok yöntem mevcuttur. Tanının erken konulması hayat kurtarıcı olabilir.

Anahtar Sözcükler: Obturator, herni, mekanik barsak obstrüksiyonu, iskemi, Howship-Romberg bulgusu

\section{Introduction}

Obturator hernia $(\mathrm{OH})$ is a rare type of pelvic hernia occurring when the pelvic contents protrude through the obturator foramen (1-8). $\mathrm{OH}$, accounts for 0.07$1.4 \%$ of all abdominal hernias. It has been known as a disease of elderly and skinny women (8-11). It occurs more frequently in the right side $(2,5,10)$. It was first described in 1724 by Arnould de Ronsil $(5,8)$. Low body mass index (BMI) and multiparity can be named among predisposing factors $(1,9)$. Symptoms and physical examination findings are not specific. Clinical diagnosis is often difficult $(4,5)$. Although advanced imaging methods facilitated more accurate preoperative diagnoses, there are many reported cases of intraoperatively diagnosed $\mathrm{OH}$ that could be diagnosed with imaging methods (2). Since it often occurs in advanced age and its diagnosis is usually made when the complications arise, $\mathrm{OH}$ may be associated with morbidity and mortality (4-6). In this paper, we present diagnostic process and treatment in two patients evaluated in the emergency department and diagnosed with $\mathrm{OH}$.
Address for Correspondence/Yazışma Adresi: Mehmet Uluşahin, Karadeniz Technical University, Farabi Hospital, Clinic of General Surgery, Trabzon, Turkey E-mail: ulusahinmehmet@hotmail.com ORCID: orcid.org/0000-0002-0212-2103 Received/Geliş Tarihi: 13 August 2018 Accepted/Kabul Tarihi: 20 November 2018

This study was presented as poster in $21^{\text {th }}$ the National Surgery Congress on April 11-15, 2018 in Antalya, Turkey
${ }^{\circ}$ Copyright 2019 by The Medical Bulletin of istanbul Haseki Training and Research Hospital The Medical Bulletin of Haseki published by Galenos Yayınevi. 'Telif Hakkı 2019 istanbul Haseki Eğitim ve Araştırma Hastanesi Haseki Tıp Bülteni, Galenos Yayınevi tarafından yayınlanmıștır. 


\section{Case Report}

\section{Case 1}

A 73-year old-female patient with a 1-year history of recurrent abdominal pain, emergency department admissions and palliative care was admitted to the emergency department with the complaints of severe abdominal pain, nausea and vomiting. She had a history of coronary angiography and hypertension, however, she had no history of previous surgical operation. She had acetylsalicylic acid and antihypertensive medication. Her BMI was calculated as $19 \mathrm{~kg} / \mathrm{m}^{2}$. Defense and rebound tenderness were observed on physical examination (PE). Howship-Romberg sign was positive. Leukocyte count was $11.400 / \mu \mathrm{L}$; other laboratory values were within the normal range. Abdominal computed tomography (CT) was performed after identifying air-fluid levels on X-ray. Emergency surgery was planned after abdominal CT revealing bilateral $\mathrm{OH}$ which was more prominent in the left side (Figure 1). Lower midline incision was performed for entering the abdominal cavity. It was intraoperatively observed that proximal small intestines were dilated and distal jejunal loops were herniated into both obturator

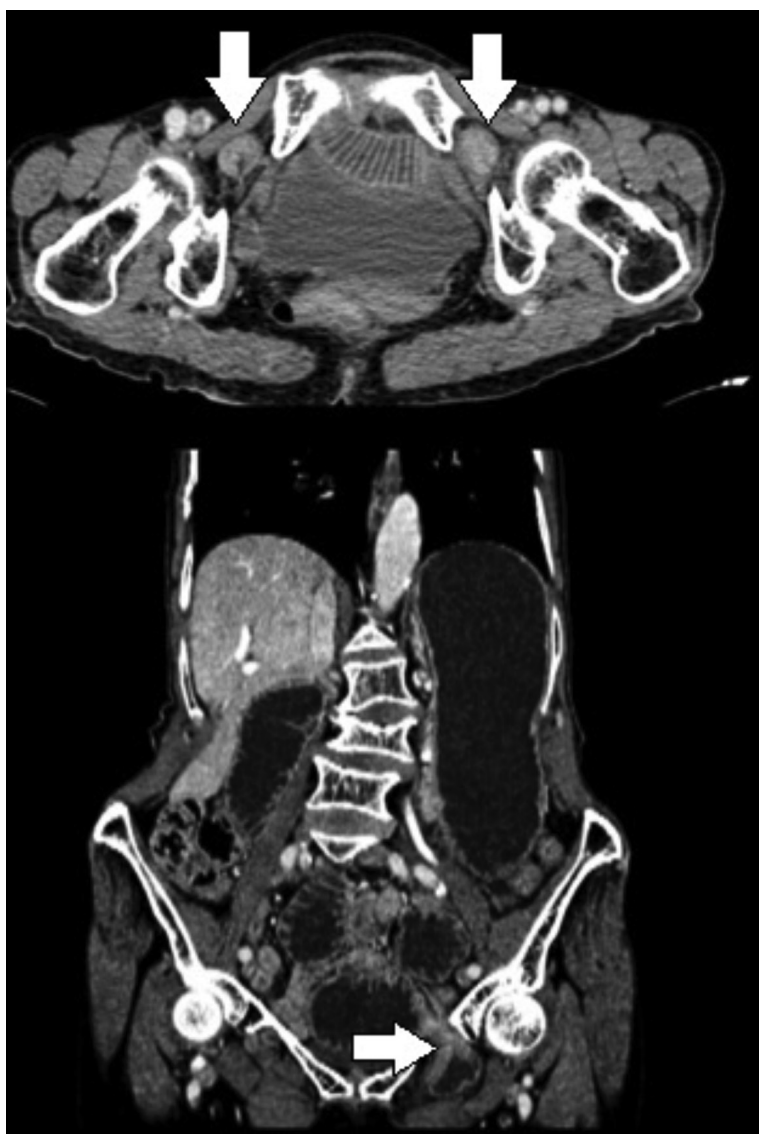

Figure 1. Appearance of bilateral obturator hernia in axial section and left obturator hernia in coronal section $\mathrm{CT}$ in case 1 canals. Herniated small intestine segments were salvaged and no ischemia findings were observed. Bilateral obturator foramens were primarily closed with polypropylene/ unabsorbable sutures. The patient was discharged on the postoperative $5^{\text {th }}$ day without any complication during postoperative period.

\section{Case 2}

An 85-year-old female patient was admitted to the emergency department with the complaints of abdominal pain, nausea and vomiting for the last 2 days. It was found that she had been admitted to emergency departments many times with similar complaints during the past 6 months. She had no concomitant disease and history of medication use. Her BMI was calculated as $18 \mathrm{~kg} /$ $\mathrm{m}^{2}$. Abdominal tenderness and guarding were identified during PE. Laboratory tests revealed a leukocyte count of $12300 / \mu \mathrm{L}$ whereas other laboratory results were normal. Air-fluid levels were present on the level of the small intestines on abdominal $\mathrm{X}$-ray. Right-sided $\mathrm{OH}$ and small intestine loops in the obturator canal were observed on abdominal $\mathrm{CT}$ images and distension in the proximal small intestine loops was also identified (Figure 2). The patient

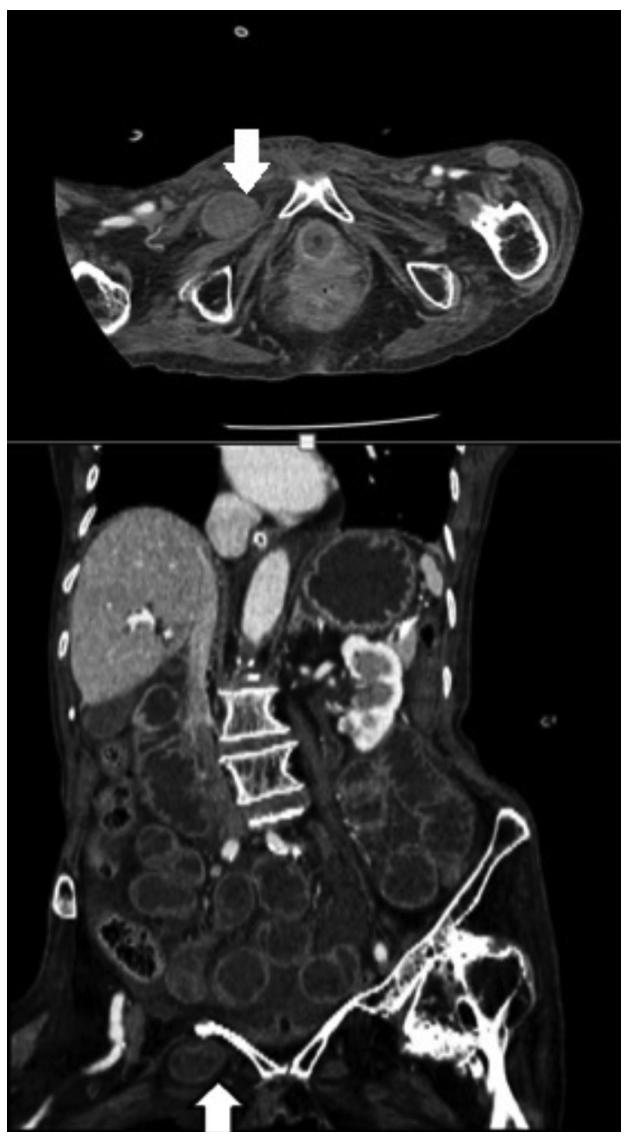

Figure 2. Appearance of right obturator hernia in axial and coronal section on $\mathrm{CT}$ in case 2 
underwent emergency surgery; the abdomen was entered through sub-umblical midline incision. During laparotomy, it was observed that an ileal segment of $5-\mathrm{cm}$ was in the right obturator canal approximately $40 \mathrm{~cm}$ proximal to the ileocecal valve; then the incarcerated valve was returned to the abdomen. Segmental small intestine resection and end-to-end anastomosis were performed due to necrotic appearance of the small intestinal loop. $\mathrm{OH}$, defect was primarily closed with 2.0 polypropylene/unabsorbable suture. The patient was discharged on postoperative day 10 without any complication during postoperative followup except atelectasis.

\section{Discussion}

$\mathrm{OH}$, is more frequent in women due to broader pelvic diameter and obturator foramen as well as decreased adipose tissue around the obturator vessels with aging and malnutrition in time $(5,8,11)$. Conditions which increase intraabdominal pressure, such as cachexia, multiparity, chronic lung disease, constipation, kyphoscoliosis and ascites, may be listed among the predisposing factors (2). Both of the patients were elderly, multiparous and cachectic.

$\mathrm{OH}$ has three stages: in the first stage, adipose and connective tissues enter into the obturator canal. The second stage is a little more advanced stage in which peritoneal sac advances downwards through the obturator canal. In the third and the last stage, symptoms are produces by herniation of the vicera into the $\operatorname{sac}(2,8)$.

Due to the fact that since signs and symptoms are often non-specific, preoperative diagnosis of $\mathrm{OH}$ is challenging, however, some findings specific for $\mathrm{OH}$ may be observed when PE is performed in detail $(1,4-7)$. Some patients may feel pain in the thigh and medial part of the knee due to compression of the anterior branch of the obturator nerve by hernia sac (Howship-Romberg finding). It may not be present in all $\mathrm{OH}$ patients; however, supports $\mathrm{OH}$ diagnosis $(5,6,8)$. Hannington-Kniff finding is another finding specific for $\mathrm{OH}$ and it manifests with loss of adductor reflex along with preservation of patellar reflex (3). Laboratory tests are often not helpful. Non-specific air-fluid levels may be seen on X-ray in some patients (2). Although ultrasonographic evaluation is generally not successful in diagnosis, it may provide information about edema and perfusion on the intestinal wall (2). Although the number of cases of preoperatively diagnosable $\mathrm{OH}$ cases has been increased along with prevalent use of abdominal $\mathrm{CT}_{\text {, there }}$ are still many $\mathrm{OH}$ cases which are only intraoperatively diagnosed $(9,11)$. Both of the patients presented in this paper had intestinal obstruction symptoms on admission and during examination.
Treatment of $\mathrm{OH}$ is emergent surgical repair (1). Both open and laparoscopic techniques are used in the management of $\mathrm{OH}(2,5)$. The most commonly used surgical technique is the abdominal approach via a low midline incision (1). Establishing a diagnosis and better exposure of the obturator ring can be listed among the advantages of this method. Obturator approach through medial side of the thigh, extraperitoneal approach with inguinal cut and retropubic retroperitoneal approach are among other surgical procedures which are rarely practiced $(1,7)$. Although intestinal obstruction is considered a relative contraindication by some authors, laparoscopic approach has been increasingly used in this patient group (4-6). Laparoscopic approach has some positive effects on the length of postoperative hospital stay and complications $(1,2,9)$. Laparoscopic repair can be performed via transabdominal or extra-peritoneal approaches. Laparoscopy provides additional advantages such as evaluation of the presence of contralateral obturator hernia. Some authors suggest a two-step approach consisting of hernia retraction through defect to the abdomen as the first step and repair as the second step in another session $(4,7)$. Synthetic mesh can be used for defect repair or primary repair can be made with non-absorbable sutures $(1,2)$. However, synthetic mesh is not suitable for patients with incarceration (1). Segmental small intestine resection may be necessary in patients with the findings of ischemia and necrosis which may cause morbidity. Respiratory, cardiac and wound-related complications may occur after $\mathrm{OH}$ operations and these complications may be fatal for elderly patients.

We used sub-umblical midline incision in our cases. Small intestine resection was performed in a patient due to the presence of necrosis. Defect was repaired with polypropylene suture in both patients.

\section{Conclusion}

Obturator hernia is a rare clinical condition with many cases still intraoperatively diagnosable despite the high diagnostic success of $\mathrm{CT}$. OH is associated with a high rate of morbidity and mortality due to intestine incarceration when treatment delays. Early diagnosis and treatment is life-saving.

\section{Authorship Contributions}

Concept: S.T., M.U., A.B.Ç. Design: S.T., M.U., A.B.Ç. Data Collection or Processing: S.T., M.U., A.G., S.T. Analysis or Interpretation: S.T., M.U., A.B.Ç., A.G., S.T. Literature Search: S.T., M.U., A.B.Ç., A.G., S.T. Writing: S.T., M.U.

Conflict of Interest: No conflict of interest was declared by the authors.

Financial Disclosure: The authors declared that this study received no financial support. 


\section{References}

1. Sá NC, Silva VCM, Carreiro PRL,et al. Rare case of incarcerated obturator hernia: Case report and review of literature. Int J Surg Case Rep 2017;37:157-60.

2. Rodriguez-Hermosa J, Codina-Cazador A, Maroto-Genover A, et al. Obturator hernia: clinical analysis of 16 cases and algorithm for its diagnosis and treatment. Hernia 2008; 12:289-97.

3. Şenol K, Bayam ME, Duman U, et al. Challenging management of obturator hernia: a report of three cases and literature review. Ulus Travma Acil Cerrahi Derg 2016;22:297-300.

4. Kohga A, Kawabe A, Cao Y, et al. Elective laparoscopic repair after reduction might be useful strategy for incarcerated obturator hernia: a case report. J Surg Case Rep 2017;9:1-4

5. Ng DCK, Tung KLM, Tang CN, et al. Fifteen-year experience in managing obturator hernia: from open to laparoscopic approach. Hernia 2014;18:381-6.
6. Hunt L, Morrison C, Lengyel J, et al. Laparoscopic management of an obstructed obturator hernia: should laparoscopic assessment be the default option? Hernia 2009;13:313-5.

7. Caine EA, Newman TH, Marzouk O, et al. Subacute bowel obstruction secondary to an obturator hernia: case report and a review of the literature. J Surg Case Rep 2017;4:1-3.

8. Perry CP, Hantes JM. Diagnosis and laparoscopic repair of type I obturator hernia in women with chronic neuralgic pain. JSLS 2005;9:138-41.

9. Liu J, Zhu Y, Shen $Y$, et al. The feasibility of laparoscopic management of incarcerated obturator hernia. Surg Endosc 2017;31:656-60.

10. Karashima R, Kimura M, Taura N, et al. Total extraperitoneal approach for incarcerated obturator hernia repair. Hernia 2016;20:479-82.

11. Erdogan D, Gulmez M, Kara VM, et al. A rare cause of acute mechanical intestinal obstruction: a strangulated obturator hernia. North Clin Istanb 2015;2:69-72. 